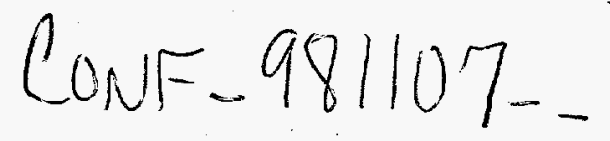

\title{
UNITED STATES DEPARTMENT OF ENERGY LARGE COMMERCIAL ABSORPTION CHILLER DEVELOPMENT PROGRAM
}

\author{
Patricia Welesko Garland \\ Oak Ridge National Laboratory \\ 600 Maryland Ave. SW, Suite 306W \\ Washington, DC 20024 \\ Robert C. DeVault \\ Abdi Zaltash \\ Oak Ridge National Laboratory \\ P.O. Box 2008 \\ Oak Ridge, Tennessee 37831-6070
}

\author{
RECEIVED \\ AUG 13 i998 \\ OSTI
}

\begin{abstract}
The U.S. Department of Energy (DOE) is working with partners from the gas cooling industry to improve energy efficiency and U.S. competitiveness by using advanced absorption technologies that eliminate the use of chlorofluorocarbons (CFCs) and hydrochlorofluorocarbons (HCFCs), refrigerants that contribute to ozone depletion and global warming. Absorption cooling uses natural gas as the heat source, which produces much lower $\mathrm{NO}_{\mathrm{x}}$ emissions than oil-or coalgenerated electricity. Gas-fired chillers also have the advantage of helping reduce peak electrical usage during summer months. To assist industry in developing advanced absorption cooling technologies, DOE sponsors the Large Commercial Chiller Development Program. The goal of the program is to improve chiller cooling efficiency by $30-50 \%$ compared with the best currently available absorption systems.
\end{abstract}

$\begin{array}{ll}\text { LIST OF SYMBOLS AND ABBREVIATIONS } \\ \text { ABSIM } & \text { ABsorption SIMulation } \\ \text { CFC } & \text { Chlorofluorocarbon } \\ \text { COP } & \text { Coefficient of Performance } \\ \text { DCC } & \text { Double-Condenser Coupling } \\ \text { DOE } & \text { Department of Energy } \\ \text { FY } & \text { Fiscal Year } \\ \text { GAX } & \text { Generator Absorber Heat Exchanger } \\ \text { GRI } & \text { Gas Research Institute } \\ \mathrm{HCFC} & \text { Hydrochlorofluorocarbon } \\ \mathrm{H}_{2} \mathrm{O} & \text { Water } \\ \text { LiBr } & \text { Lithium Bromide } \\ \text { NH } & \text { Ammonia } \\ \text { ORNL } & \text { Oak Ridge National Laboratory } \\ \text { RFP } & \text { Request for Proposal }\end{array}$

\section{INTRODUCTION}

Absorption chillers using $\mathrm{NH}_{3} / \mathrm{H}_{2} \mathrm{O}$ and $\mathrm{LiBr} / \mathrm{H}_{2} \mathrm{O}$ absorption pairs for commercial and residential use were widely available during the $1950 \mathrm{~s}$ and $1960 \mathrm{~s}$. The $\mathrm{NH}_{3} / \mathrm{H}_{2} \mathrm{O}$ pairs are traditionally used in small absorption chillers (typically 3 to 5 refrigeration tons in capacity), and virtually all large commercial chillers use $\mathrm{LiBr} / \mathrm{H}_{2} \mathrm{O}$ absorption fluids. The initial $\mathrm{LiBr} / \mathrm{H}_{2} \mathrm{O}$ absorption units used a single-effect cycle employing an evaporator, an absorber, a generator, and a condenser. Theoretically, more complex, higher-efficiency cycles were possible and had been proposed early in the century. However, it was not until the late 1950 s that the first operating prototypes were developed when researchers added a second generator and condenser to the single-effect cycle. This design is called a double-effect cycle.

The first $\mathrm{LiBr} / \mathrm{H}_{2} \mathrm{O}$ double-effect machine was built in 1956-1959 by J. S. Swearingen and E.P. Whitlow in a program sponsored by the American Gas Association. A small number of custom-built doubleeffect chillers were manufactured afterward. This double-effect cycle has been extensively improved upon, and such machines are sold throughout the world by numerous United States and Japanese corporations.

In the late 1960 s, U.S. manufacturers had $100 \%$ of the worldwide market for $\mathrm{LiBr} / \mathrm{H}_{2} \mathrm{O}$ absorption chillers using the standard single-effect absorption cycle (see Figure 1). The Trane Company introduced the first mass-produced steam-fired double-effect $\mathrm{LiBr} / \mathrm{H}_{2} \mathrm{O}$ absorption chiller in 1972.

Several factors have influenced absorption chiller sales since that time. The first factor was the entry of the Japanese manufacturers into the marketplace in the late 1960s. Japanese manufacturers were the first to introduce direct-fired double-effect chillers, which now account for the majority of absorption chiller sales throughout the world. Japanese manufacturers have continuously updated and improved the single-effect and double-effect technologies, further increasing their share of the market. The second factor influencing sales was the 1970s "energy
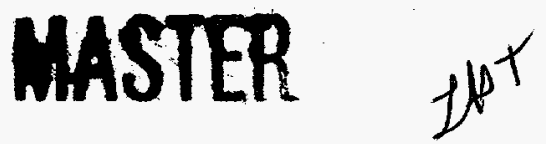


\section{DISCLAIMER}

This report was prepared as an account of work sponsored by an agency of the United States Government. Neither the United States Government nor any agency thereof, nor any of their employees, makes any warranty, express or implied, or assumes any legal liability or responsibility for the accuracy, completeness, or usefulness of any information, apparatus, product, or process disclosed, or represents that its use would not infringe privately owned rights. Reference herein to any specific commercial product, process, or service by trade name, trademark, manufacturer, or otherwise does not necessarily constitute or imply its endorsement, recommendation, or favoring by the United States Government or any agency thereof. The views and opinions of authors expressed herein do not necessarily state or reflect those of the United States Government or any agency thereof. 


\section{DISCLAIMER}

Portions of this document may be illegible in electronic image products. Images are produced from the best available original document. 


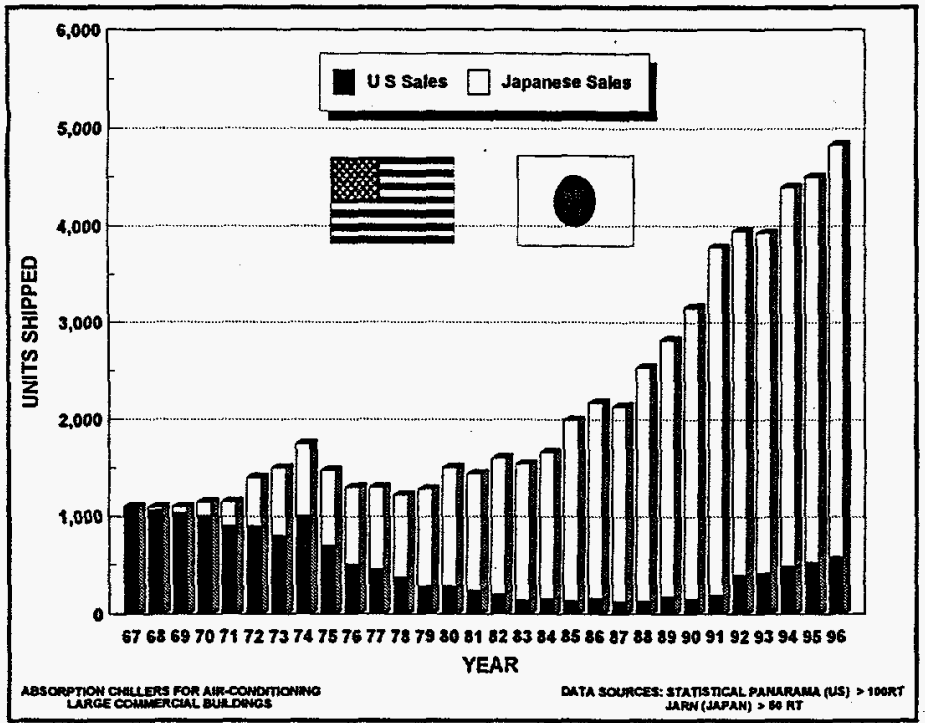

Figure 1. Worldwide Sales of U.S. and Japanese Large Commercial Chillers.

crisis." Natural gas prices and fuel availability concerns caused absorption chiller sales to fall in the mid-1970s. Since then, absorption chiller sales have recovered and have continued strong growth in the 1980 s and 1990 s with relatively stable fuel prices and availability throughout the world. Currently, Japanese manufacturers continue to dominate worldwide manufacturing of absorption chillers using singleeffect and double-effect cycles.

DOE is working through a cost-shared program with U.S. industry to improve economic competitiveness and energy efficiency by designing, building, and testing a triple-effect absorption chiller.

Figure 2 shows relative energy usage for single-, double-, and tripleeffect large commercial absorption chillers. The relative energy usage is defined as the energy used relative to that of a single-effect chiller for the same cooling capacity. Currently, no triple-effect absorption chillers are sold commercially. The goal of DOE's program is to build a U.S.developed triple-effect chiller that improves cooling efficiency by 30 to 50 percent, compared with double-effect absorption chillers currently on the market, while keeping the cost premium low and addressing manufacturability.

Gas-fired absorption heating and cooling systems offer many benefits to consumers, utilities, and the regional and global environment. For end users, they offer energy efficiency and attractive economic payback. For utilities, they offer opportunities to reduce peak demand for electricity and improve fuel use through integrated resource planning and demand-side management, benefitting both gas and electric utilities. For the nation, advanced gas heating and cooling products would create new jobs in the United States and improve U.S. competitiveness in international markets. Additionally, this environmentally benign technology eliminates the use of ozone-depleting CFC and HCFC refrigerants.

The Office of Building Technologies of DOE supports privatesector efforts to develop gas-fired absorption heating and cooling technologies through its Thermally Activated Heat Pump Program. Oak Ridge National Laboratory (ORNL) manages this program for DOE.

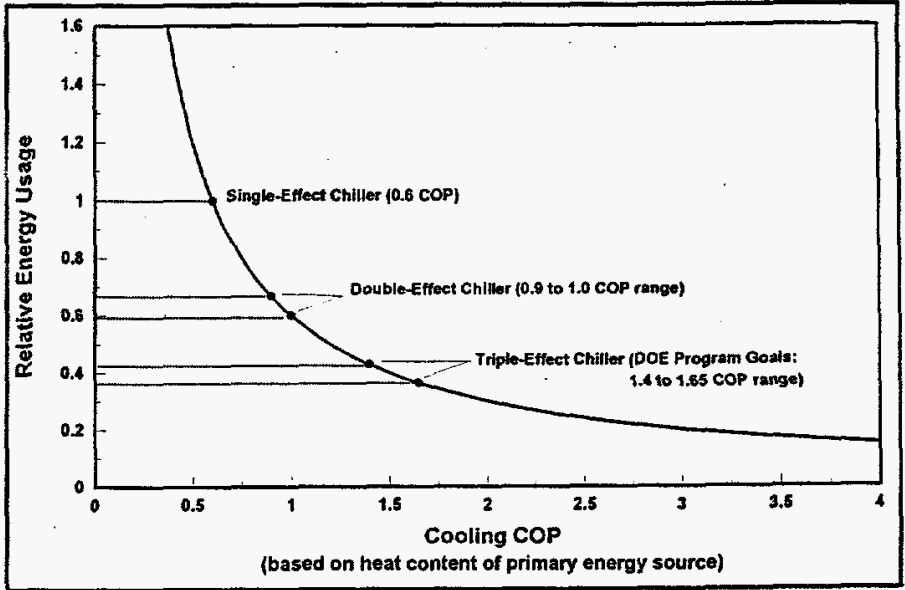

Figure 2. Large Commercial Chiller Energy Usage as Compared to a Single-Effect Chiller at Same Cooling Capacity.

\section{PROJECT HISTORY}

\section{Advanced Cycles Background}

DOE research on absorption heat pumps was first conducted in FY 1977 by Arkla Industries Inc., in Evansville, Indiana, and Allied Chemical Corporation in Morristown, New Jersey. Arkla developed a residential system using $\mathrm{NH}_{3} / \mathrm{H}_{2} \mathrm{O}$ as the absorption fluids. Allied Chemical developed a residential system using R133a/ETFE as the working fluid pair. Phillips Engineering Inc., of St. Joseph, Michigan, performed prototype development as a subcontractor to Allied Chemical.

Arkla manufactured a residential and light commercial $\mathrm{NH}_{3} / \mathrm{H}_{2} \mathrm{O}$ single-effect absorption chiller. Arkla developed a single-effect $\mathrm{NH}_{3} / \mathrm{H}_{2} \mathrm{O}$ heat pump concept that was for heating only. It was based as much as possible on Arkla's chiller product. The Arkla heat pump was laboratory tested in the United States and field tested in Germany by Bosch-Junkers for one winter season. A heating COP of 1.25 was measured.

The Allied Chemical absorption unit was tested for heating and cooling in St. Joseph, Michigan, for more than a year. This test recorded COPs of 1.2 in heating and 0.5 in cooling, which were close to program performance goals, and demonstrated the operation and reliability of the sealed absorption system.

Manufacturing cost studies were performed for both the Arkla and Allied prototypes. Both proved to be uneconomical for the majority of potential residential customers (more than a 3-year payback in most U.S. locations).

Based on the performance and manufacturing costs of the singleeffect prototypes, the absorption program goals were reevaluated in 1981 . The decision was made to look for advanced cycle absorption heat pumps capable of higher efficiencies than conventional single-effect units. Performance goals were based on efficiencies necessary to achieve good customer economics in most U.S. locations. The novel advanced absorption cycles were to use existing fluids.

In 1982, a Request for Proposal (RFP) was issued to develop advanced cycle absorption heat pumps. The target COPs were set at 1.6 in heating and 0.7 in cooling. The market was residential and commercial, and capacities ranged from 3 to 1000 tons (10.5 to 3500 $\mathrm{kW}$ ). Accomplishing these goals would produce systems that could save $50 \%$ or more of the energy used for space conditioning and water heating 
by then current state-of-the-art gas furnaces and boilers.

The Advanced Absorption Cycles Heat Pump Program began in 1983. The research was carried out in three phases. Phase I was the evaluation of concepts leading to high-efficiency advanced cycle heat pumps. Phase II was the fabrication and proof testing of a laboratory breadboard, and Phase III was the fabrication of an engineering prototype for laboratory testing and field demonstrations. Contractors selected to do the research were Phillips Engineering, Inc., Trane, and the Carrier Corporation.

All three companies selected "preferred" advanced absorption heat pump cycles under Phase I efforts. Phillips Engineering selected a residential heat pump concept using the generator absorber heat exchanger (GAX) cycle. Trane selected a commercial version of the GAX cycle. Carrier selected a commercial-size unit using a patented dual-loop heat pump system.

All three companies conducted Phase II proof-of-principle laboratory demonstrations of their selected advanced cycles. Both Trane and Carrier built and successfully tested their selected advanced cycles for large commercial heat pump applications (heating and cooling) . Both commercial heat pump technologies would require substantial new investment in tooling and equipment (for the components containing ammonia refrigerant). For this reason, both heat pumps proved to be costly to build, resulting in high predicted initial selling price to the customer. As a result, reasonable economic payback was obtained only in high heating load northern climate applications( where heating represented about $80 \%$ percent of the annual heating/cooling load). Since the great majority of large commercial buildings have predominately air-conditioning loads (rather than heating loads), this meant that there would only be a small "niche" market for these new heat pump products in large commercial buildings. At the end of the phase II effort, both Trane and Carrier decided not to continue with a Phase III effort, since the potential market was small. Phillips Engineering was the first to demonstrate Phase II hardware by building and successfully testing a laboratory breadboard prototype in 1984-1985. This residential heat pump breadboard demonstrated significant efficiency improvement, having a heating coefficient of performance (COP) of 1.6 to 1.8 at $47^{\circ} \mathrm{F}$ or $8^{\circ} \mathrm{C}$ (electric resistance input, but excluding electric parasitic power) and a cooling COP of 0.7 to 0.9 at $95^{\circ} \mathrm{F}$ or $35^{\circ} \mathrm{C}$ (Phillips 1991).

While the advanced cycle programs were underway at Phillips, Trane, and Carrier, it became evident that additional research and development in the commercial cooling area was needed (since cooling loads predominate in most large commercial buildings). ORNL conducted scoping studies aimed toward improving the cooling performance of large commercial chillers. These studies led to DOE-owned patents for two distinctly different Triple-Effect absorption chiller cycles. These particular triple-effect cycles are potentially $30 \%$ to $50 \%$ more efficient than the best existing absorption chillers (Japanese double-effect machines). After the completion of Phase II of the Advanced Absorption Cycles Heat Pump Program, Trane licensed one of these two patented Triple-Effect cycles and continues to develop laboratory prototypes, with Gas Research Institute (GRI) co-funding.

\section{Triple-Effect Cycles}

Currently, no triple-effect absorption chillers are sold commercially. Previous work has shown that there are theoretically a large number of cycles that fall into the category of "triple-efficiency" (Whitlow 1994, Alefeld 1985, Oouchi 1985, Miyoshi et al. 1985, DeVault 1988, DeVault and Biermann 1993, and Rockenfeller and Sarkisian 1994). The basic three-condenser, three-desorber $\mathrm{LiBr} / \mathrm{H}_{2} \mathrm{O}$ triple-effect cycle was patented by Oouchi et al. (1985). A "dual-loop" triple-effect cycle was patented by ORNL under the DOE Thermally Activated Heat Pump Program (DeVault 1988). A pressure versus temperature representation for the "dual-loop" triple-effect cycle is shown in Figure 3.

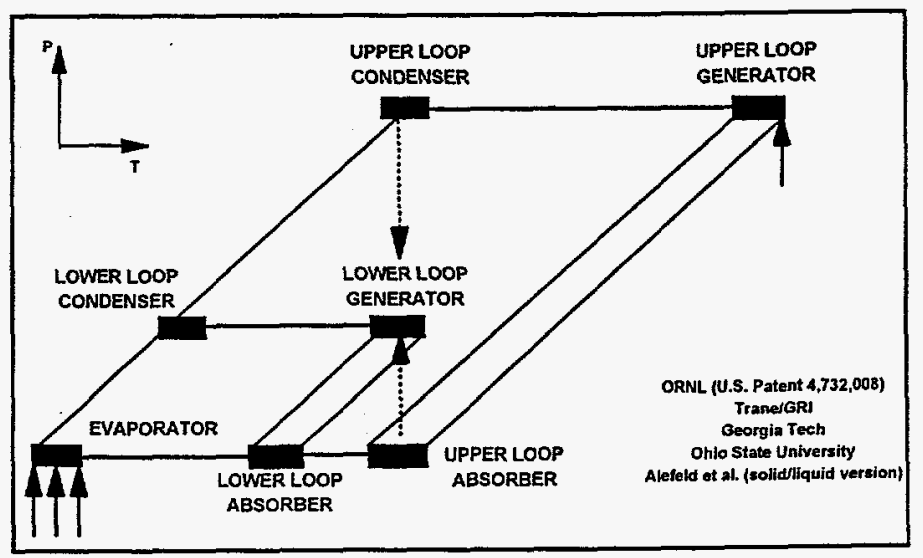

Figure 3. Pressure vs. Temperature Diagram for the Dual-Loop Triple-Effect Cycle.

As previously mentioned, Trane licensed this triple-effect technology from ORNL in 1989. With support from GRI, Trane has built two operational triple-effect prototype chillers of greater than 100-ton $(350 \mathrm{~kW})$ capacity, both of which have undergone optimization and characterization testing. Trane's product goal is a 50 percent improvement in COP with no more than a 25 percent cost premium over the current double-effect chillers on the market.

Since the Trane/GRI dual-loop, triple-effect program was under way, DOE and ORNL conducted additional scoping studies to identify promising alternative triple-effect technologies. A parallel program for development of an alternative technology would improve the U.S. potential for getting a triple-effect chiller to market. Alternate technologies were extensively reviewed, including 3-, 4-, 5-, 6- and 7effect cycles. One particular triple-effect cycle, using a double-condenser coupling (DCC) concept, emerged as the best alternative and was patented by ORNL in 1993 (DeVault and Biermann 1993). A pressure versus temperature representation for the DCC concept is shown in Figure 4.

Separately, in 1990, an RFP was issued to develop and proof-test basic technology needed for high-temperature operation of $\mathrm{LiBr} / \mathrm{H}_{2} \mathrm{O}$ for absorption chiller cycles. The contractor selected to perform the research was Battelle Memorial Institute in Columbus, Ohio, with York International of York, Pennsylvania, as a subcontractor. Battelle performed materials and additive evaluations that are summarized in Section 3 and described in detail by Hanna (1997). As the work progressed toward the development stage, ORNL contracted with York International to review several cycle possibilities for $\mathrm{LiBr} / \mathrm{H}_{2} \mathrm{O}$ tripleeffect absorption water chillers. The objective of the triple-effect research is to build fully functional hardware to demonstrate a practical triple-effect chiller for commercial air-conditioning applications. Analytical models were used to predict the performance of alternative cycles and to guide design and testing of prototype hardware. The design 


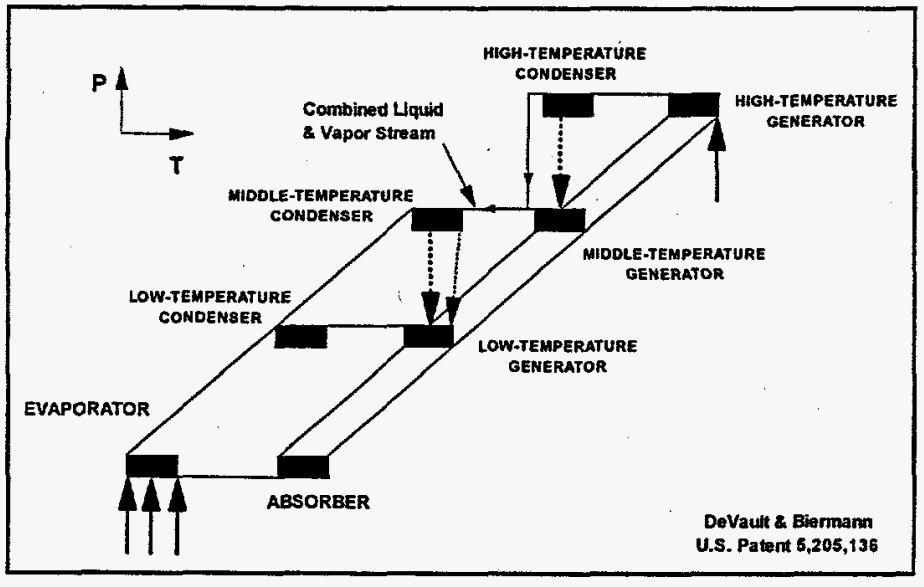

Figure 4. Pressure vs. Temperature Diagram for the DCC TripleEffect Cycle

goal for the prototype is to achieve 400 tons (1400 kW) of cooling capacity. Work performed by York International is described later on.

Battelle Memorial Institute: Development and Proof Testing of Basic Technology Needed for High-Temperature Operation of Absorption Chiller Cycles

This section summarizes the materials and additive evaluations completed by Battelle Memorial Institute as part of the Large Commercial Chiller Program.

\section{Background}

The triple-effect absorption cycle, named for using the input energy at three different temperature levels, provides higher system performance than single- and double-effect absorption cycles when a heat source of a sufficiently high temperature is available. For a typical triple-effect $\mathrm{LiBr}$ chiller design, the highest required generator temperatures are in the range of 400 to $500^{\circ} \mathrm{F}\left(204\right.$ to $\left.260^{\circ} \mathrm{C}\right)$. At these temperatures, there is evidence that the industry standard additive, 2-ethyl-1-hexanol (2EH), may decompose so rapidly that it is unsuitable. Effective additives and/or additive separation techniques - as well as a combination of materials and corrosion inhibitors suitable for use at the required high temperatures-are needed to support promising current R\&D in hightemperature technologies.

\section{Objective}

The objective is to describe development and proof testing in two areas of basic technology: (1) the design, building, and testing of components and subsystems to separate conventional additives (2EH) from a flowing stream of solution to minimize potential decomposition in a high-temperature generator; and (2) identification and evaluation of three potential corrosion inhibitors for use at 400 to $500^{\circ} \mathrm{F}(204$ to $260^{\circ} \mathrm{C}$ ) that would allow the use of cost-effective construction materials in a triple-effect $\mathrm{LiBr}$ chiller.

\section{Approach}

The approach to the additive separation objectives was to identify and screen alternative technologies for separating the absorber additive from the solution, evaluate the best candidates in bench-scale experiments, and test the best of these in full-scale chiller tests.

To examine materials compatibility, Battelle conducted a series of materials/inhibitor tests using sample coupons, leading to the selection of the most promising low-cost alternatives and the evaluation of these in dedicated; closed-loop tests. These closed-loop tests provided information on the gas generation rate for the material/inhibitor combinations of interest and information on the physical response of the material/inhibitor combinations to two-phase flow conditions.

\section{Results}

An important element of this project was the evaluation of methods to enhance the performance of the absorber in a triple-effect chiller by separating the additive from the solution stream that enters the generator. A review of means of separating two liquids identified only a few techniques that appeared to be both simple and potentially effective. The separation results showed that additives such as $2 \mathrm{EH}$ probably cannot economically be separated from the solution in gravimetric or reboiler chambers. The alternatives are to use only additives with hightemperature stability, to continue to use $2 \mathrm{EH}$ as the additive but to replenish its charge, or to identify and develop a new separation technique.

Another major issue in the development of high-temperature absorption cycles has always been the identification of corrosion inhibitors and construction materials that are adequate for the expected operating conditions. Results showed the potential for using both molybdate and a new inhibitor as independent corrosion inhibitors in the 400 to $500^{\circ} \mathrm{F}$ ( 204 to $260^{\circ} \mathrm{C}$ ) $\mathrm{LiBr}$ solutions. The new inhibitor showed potential for inhibiting stress-corrosion cracking in 304 and 316 stainless steels.

\section{Conclusions}

The additive separation efforts on this project did not lead to the clear identification of an attractive means to enhance absorber performance in a chiller having a generator operating temperature in the 400 to $500^{\circ} \mathrm{F}\left(204\right.$ to $\left.260^{\circ} \mathrm{C}\right)$ range. The separation tests conducted in this project led to the conclusion that additives such as $2 \mathrm{EH}$ (the industry standard) probably cannot economically be separated from the $\mathrm{LiBr}$ solution by using gravimetric, thermal, or electroacoustic techniques.

The materials compatibility efforts on this project showed the potential for using molybdate and the new inhibitor as independent corrosion inhibitors in 400 to $500^{\circ} \mathrm{F}\left(204\right.$ to $260^{\circ} \mathrm{C}$ ) $\mathrm{LiBr}$ solutions.

York International: Design, Construction, and Testing of a Prototype Advanced Absorption Chiller

This section summarizes the ongoing effort at York International in support of the Large Commercial Chiller Program.

\section{Objective}

The DOE Large Commercial Chiller Program involves research, development, and evaluation of multiple triple-effect designs. In a costshared subcontract, York International has reviewed several cycle 
possibilities for $\mathrm{LiBr} / \mathrm{H}_{2} \mathrm{O}$ triple-effect absorption chillers. York is currently investigating the DCC base cycle. The objective of this project is to build fully functional hardware to demonstrate a practical tripleeffect chiller for commercial air-conditioning applications. The design goal for the prototype is to achieve 400 tons (1400 kW) of cooling capacity.

\section{Approach}

The planned work was divided into four phases. Phase I was heat and mass transfer additive evaluation, which is a critical technical issue in developing the triple-effect chiller. Phase II is for the preliminary evaluation of candidate cycles, cost barriers, and development work on the critical technologies. Phase III is devoted to final prototype fabrication and testing. Phase IV is a field demonstration of one or more full-size prototypes.

\section{Results}

To support York's Phase I effort, analytical and experimental work was performed by the University of Maryland, Pennsylvania State University, and Rocky Research to evaluate the stability and performance of new alcohol additives at triple-effect temperatures. A survey and testing of alternate additives was performed at each location.

In parallel, the Phase II effort consisted of performing various cycle evaluations using ABSIM (Grossman 1995), a modular and flexible computer code for simulation of absorption systems. In addition, York engineers have developed a computer modeling program that does component as well as cycle analyses. This program (dubbed "Hesim" after one the program's authors, Xiaoyu He) uses the equipment input parameters (e.g., water temperatures, concentrations) and the calculated heat transfer coefficients to determine maximum operating temperature and COP, as well as other state point values. These values can then be compared with actual operating conditions.

The positive results of the Phase I and Phase II efforts (including a preliminary scoping study to evaluate cost barriers) led York International to make a "go" decision to build the laboratory prototype under the Phase III effort.

Phase III consists of several tasks, including final design and construction of the prototype chiller and test facility and laboratory testing of the prototype chiller. The prototype chiller at York has been fabricated and is currently undergoing preoperational testing. A computer program was developed that displays the triple-effect prototype and corresponding state point data during prototype testing. In addition, the program has data reduction capabilities and can calculate capacity, COP, and the individual heat transfer coefficients of each major component in real time. Computer modeling of the cycle and operation of the components will be performed throughout the prototype test program. Prototype testing will continue throughout this calendar year. A one-yearlong field test program will begin next year.

DOE/ORNL is providing development support and technical guidance to York International in this cost-shared program to develop a triple-effect absorption chiller prototype. GRI has also shared in the cost of this program. DOE and ORNL are working with the American Gas Cooling Center and with manufacturers and gas utilities to disseminate information related to commercial gas cooling technologies.

\section{Conclusions}

Testing of the prototype chiller has just begun and will continue until the end of this calendar year. In an iterative process, results of the prototype testing will be integrated into the design of the field test unit and cost and scoping studies.

\section{ACKNOWLEDGEMENTS}

The authors would like to thank the Office of Building Technologies, State and Community Program (BTS), U.S. Department of Energy, in Washington D.C. for supporting this work. This work was conducted under contract No. DE-AC05-96OR22464 with Lockheed Martin Energy Research Corporation.

\section{REFERENCES}

Alefeld, G., 1985, "Multi-Stage Apparatus Having Working-Fluid and Absorption Cycles, and Method of Operation Thereof," U.S. Patent $4,531,374$.

DeVault, R. C., 1988, "Triple-Effect Absorption Chiller Utilizing Two Refrigerant Circuits," U.S. Patent 4,732,008.

DeVault, R. C., and Biermann, W. J., 1993, "Triple-Absorption Refrigeration System With Double-Condenser Coupling," U.S. Patent $5,205,136$.

Grossman, G., 1995, ABSIM-Modular Simulation of Absorption Systems, User's Guide and Reference, Version 1.2, Oak Ridge National Laboratory.

Hanna, W. T., 1977, Development and Proof Testing of Basic Technology Needed for High Temperature Operation of LiBr/H2O for Absorption Chiller Cycles, ORNL/Sub/86X-SS280/1, January.

Miyoshi, N., Sugimoto, S., and Aizawa, M., 1985, "Multi-Effect Absorption Refrigerating Machine," U.S. Patent 4,551,991.

Oouchi, T., Usui, S., Fukuda, T., and Nishiguchi, A., 1985, "MultiStage Absorption Refrigeration System," U. S. Patent, 4,520,634.

Phillips, B. A., and DeVault, R. C., 1991, "Residential Absorption Heat Pump Using a Generator-Absorber Heat Exchange Cycle," Proceedings: Intersociety Energy Conversion Engineering Conference, Boston, August.

Rockenfeller, U., and Sarkisian, P., 1994, "Triple-Effect Absorption Cycle Apparatus," U.S. Patent 5,335,515.

Whitlow, E. P., 1994, Personal communication. 